\title{
Fibrodysplasia ossificans progressiva
}

INSERM

\section{Source}

INSERM. (1999). Orphanet: an online rare disease and orphan drug data base.

Fibrodysplasia ossificans progressiva. ORPHA:337

Fibrodysplasia ossificans progressiva (FOP) is a severely disabling heritable disorder of connective tissue characterized by congenital malformations of the great toes and progressive heterotopic ossification that forms qualitatively normal bone in characteristic extraskeletal sites. 